\title{
PENERAPAN MODEL PEMBELAJARAN STUDENT TEAMS ACHIEVEMENT DIVISION (STAD) MELALUI MEDIA PEMBELAJARAN ULAR TANGGA UNTUK MENINGKATKAN KEMAMPUAN BERPIKIR KRITIS DAN HASIL BELAJAR IPS PADA PESERTA DIDIK KELAS 2 SD
}

\author{
Dyah Anggraini ${ }^{1}$, Stefanus Relmasira ${ }^{2}$, Agustina Tyas Asri Hardini ${ }^{3}$ \\ 1Pendidikan Guru Sekolah Dasar, Universitas Kristen Satya Wacana, dyahanggaraini1987@gmail.com \\ 2Pendidikan Guru Sekolah Dasar, Universitas Kristen Satya Wacana, stefanus.relmasira@staaf.uksw.edu \\ 3Pendidikan Guru Sekolah Dasar, Universitas Kristen Satya Wacana, tyas.asri@staff.uksw.edu
}

\section{INFO ARTIKEL}

Riwayat Artikel:

Diterima: 27-03-2018

Disetujui: $10-04-2018$

\section{Kata Kunci:}

Kemampuan Berpikir

Kritis

Model STAD

Ular Tangga

\section{ABSTRAK}

\begin{abstract}
Abstrak: : Jenis penelitian ini adalah penelitian tindakan kelas yang bertujuan untuk meningkatkan kemampuan berpikir kritis dan hasil belajar IPS peserta didik kelas 2 SDN Kutowinangun 07 dengan menggunakan model STAD berbantuan media pembelajaran ular tangga. Hasil penelitian menunjukkan adanya peningkatan kemampuan berpikir kritis peserta didik, yang awalnya pra tindakan 1,49 (kurang kritis), siklus I menjadi 2,22 (cukup kritis) dan siklus II menjadi 2,85 (kritis). Demikian juga dengan hasil belajar peserta didik yang semula pada pembelajaran pra tindakan 4 peserta didik $(26,67 \%)$ yang tuntas di siklus I terdapat 11 peserta didik $(73,33 \%)$ yang tuntas dan siklus II ada 14 peserta didik (93,33\%) yang tuntas.

Abstract: : This type of research is a classroom action research that aims to improve the ability of critical thinking and learning outcomes of 2nd grade students of SDN Kutowinangun 07 by using STAD model assisted by learning media of snake ladder. The results showed an increase in students' critical thinking skills, initially preaction 1.49 (less critical), cycle I to 2.22 (critical enough) and cycle II to 2.85 (critical). Similarly, the learning outcomes of learners who initially on the pre-action learning 4 students (26.67\%) completed in the first cycle there are 11 students (73.33\%) is complete and cycle I/ there are 14 students (93.33\%) thoroughly.
\end{abstract}

\section{A. LATAR BELAKANG}

Kemampuan berpikir tingkat tinggi merupakan salah satu kompetensi yang penting dalam era globalisasi seperti saat ini sehingga wajib dimiliki oleh setiap peserta didik. Menurut Siswono (Amir, 2015:160) berpikir kritis tergolong salah satu kategori berpikir tingkat tinggi (High Order Thinking). Menurut Amir (2015:162) berpikir kritis merupakan kegiatan intelektual seseorang dalam mengumpulkan, mengategorikan, menganalisa, dan mengevaluasi informasi ataupun data agar dapat membuat suatu kesimpulan untuk memecahkan masalah yang disajikan. Zubaedi menuturkan bahwa tujuan berpikir kritis adalah pembentukan sifat bijaksana dan memungkinkan peserta didik menganalisis informasi secara teliti dan membuat kesimpulan yang tepat dalam menghadapi masalah (Sulistiana: 2015:125).

Kemampuan berpikir kritis diperlukan pada pelajaran IPS karena pada pelajaran IPS tidak hanya berupa hafalan materi/ingatan saja melainkan meliputi aspek pengetahuan, keterampilan dan juga nilai. Menurut Kristin (2013:56) "pelajaran IPS di tingkat sekolah pada dasarnya bertujuan untuk mempersiapkan para peserta didik sebagai warga negara yang memahami pengetahuan (knowledge), keterampilan (skill), sikap dan nilai (attitudes and values) yang dapat digunakan sebagai kompetensi untuk menyelesaikan masalah pribadi atau masalah sosial serta kemampuan menarik keputusan dan berpartisipasi dalam berbagai kegiatan masyarakat agar menjadi warga negara yang baik.

Menurut Etin Solihatin \& Raharjo "tujuan dari pelajaran IPS adalah untuk mendidik dan memberi bekal kemampuan dasar kepada peserta didik untuk mengembangkan diri sesuai dengan bakat, minat, kemampuan dan lingkungannya, serta sebagai bekal bagi peserta didik untuk melanjutkan pendidikan ke jenjang yang lebih tinggi” (Kristin, 2016:76). Mata pelajaran IPS dirancang untuk menumbuhkan 
kemampuan peserta didik agar menjadi anggota masyarakat yang memiliki pengetahuan, pemahaman, keterampilan dan kemampuan menjabarkan terhadap kondisi sosial masyarakat dalam memasuki kehidupan yang dinamis (Rahman: 2013,155). Dalam mengajarkan pelajaran IPS guru harus memilih strategi pembelajaran yang sesuai agar tujuan IPS dapat tercapai. Strategi tersebut meliputi model dan media pembelajaran. Model pembelajaran merupakan cara yang digunakan guru dalam menyampaikan materi kepada peserta didik, sedangkan media pembelajaran berfungsi sebagai alat bantu dalam kegiatan belajar agar peserta didik mampu memahami konsep dan materi yang dipelajari. Media pembelajaran harus disesuaikan dengan materi yang akan diajarkan, tidak semua media dapat digunakan untuk membantu memahami materi tertantu. Guru harus bijak dalam memadukan model, media pembelajaran dan materi pelajarannya.

Berdasarkan pengalaman penulis selama mengajar di kelas 2, hasil belajar IPS peserta didik masih rendah. Ini terlihat dari hasil Ulangan Akhir Semester I selama 3 tahun berturut-turut hasil belajar masih dibawah KKM yang sudah ditentukan. Berikut disajikan tabel hasil belajar IPS:

TABEL 1

DATA NILAI UAS I IPS

\begin{tabular}{|l|c|c|l|}
\hline $\begin{array}{l}\text { Tahun } \\
\text { Pelajaran }\end{array}$ & KKM & $\begin{array}{l}\text { Frekwensi dan } \\
\text { Presentase } \\
\text { Peserta didik } \\
\text { yang tuntas }\end{array}$ & $\begin{array}{l}\text { Frekwensi } \\
\text { dan } \\
\text { Presentase } \\
\text { Peserta didik } \\
\text { yang tidak } \\
\text { tuntas }\end{array}$ \\
\hline $2014 / 2015$ & 70 & $11(39 \%)$ & $17(61 \%)$ \\
\hline $2015 / 2016$ & 70 & $8(38 \%)$ & $11(62 \%)$ \\
\hline $2016 / 2017$ & 70 & $6(35 \%)$ & $11(65 \%)$ \\
\hline
\end{tabular}

Bukan hanya hasil belajar IPS yang masih rendah tetapi juga kemampuan berpikir kritis peserta didik masih rendah. Hal ini terlihat pada saat peserta didik diberikan pertanyaan hanya beberapa peserta didik yang menjawab, jawaban yang diberikan baru sebatas ingatan saja belum merupakan hasil berpikir kritis mereka dalam menganalisis suatu pertanyaan atau masalah. Peserta didik tampak kesulitan dalam mengungkapkan pendapat atau jawaban mereka. Pertanyaan yang diajukan peserta didik belum menunjukkan pertanyaan yang kritis. Penulis dalam proses mengajar belum memadukan antara model dan media pembelajaran. Keterampilan penulis yang belum optimal dan kemampuan berpikir kritis peserta didik yang masih belum terlihat mengakibatkan hasil belajar peserta didik masih rendah.

Untuk meningkatkan kemampuan berpikir kritis peserta didik, salah satu model pembelajaran yang dapat diterapkan adalah model pembelajaran STAD. Pemilihan model pembelajaran STAD didasarkan pada pendapat Hosnan (2014:206) model ini berguna untuk mengembangkan kemampuan kerja sama, kreatif, berpikir kritis, dan ada kemauan untuk membantu teman serta merupakan pembelajaran kooperatif yang paling sederhana. Menurut Trianto (2010:68) pembelajaran kooperatif tipe STAD adalah pembelajaran yang menggunakan kelompok-kelompok kecil dengan anggota tiap kelompok 4-5 orang secara heterogen. Model pembelajaran STAD lebih menekankan kegiatan dan interaksi diantara peserta didik untuk saling memotivasi dan membantu memahami materi pelajaran untuk mencapai hasil yang optimal.

\section{TABEL 2}

FASE-FASE MODEL PEMBELAJARAN STAD

\begin{tabular}{|l|l|}
\hline \multicolumn{1}{|c|}{ Fase } & \multicolumn{1}{c|}{ Kegiatan Guru } \\
\hline $\begin{array}{l}\text { Fase } 1 \\
\text { Menyampaikan tujuan dan memotivasi peserta didik }\end{array}$ & $\begin{array}{l}\text { Menyampaikan tujuan pembelajaran yang akan dicapai serta } \\
\text { memotivasi peserta didik belajar }\end{array}$ \\
\hline $\begin{array}{l}\text { Fase } 2 \\
\text { Menyajikan/menyampaikan informasi }\end{array}$ & $\begin{array}{l}\text { Menyampaikan informasi pada peserta didik dengan cara } \\
\text { mendemonstrasikan atau lewat bahan bacaan }\end{array}$ \\
\hline $\begin{array}{l}\text { Fase } 3 \\
\text { Mengkoordinasi peserta didik dalam kelompok-kelompok } \\
\text { belajar }\end{array}$ & $\begin{array}{l}\text { Menjelaskan cara membentuk kelompok belajar dan } \\
\text { membantu peserta didik melakukan transisi secara efisien }\end{array}$ \\
\hline $\begin{array}{l}\text { Fase } 4 \\
\text { Membimbing kelompok bekerja dan belajar }\end{array}$ & Membimbing kelompok belajar pada saat mengerjakan tugas \\
\hline $\begin{array}{l}\text { Fase } 5 \\
\text { Evaluasi }\end{array}$ & $\begin{array}{l}\text { Mengevaluasi hasil belajar atau masing-masing kelompok } \\
\text { mempresentasikan hasil kerjanya }\end{array}$ \\
\hline $\begin{array}{l}\text { Fase } 6 \\
\text { Memberikan penghargaan }\end{array}$ & $\begin{array}{l}\text { Menghargai baik upaya maupun hasil belajar individu dan } \\
\text { kelompok }\end{array}$ \\
\hline
\end{tabular}

(Trianto, 2010:66-67)

Model pembelajaran akan lebih menarik perhatian peserta didik dalam menerima pembelajaran jika memadukan dengan media pembelajaran. Daryanto (2012:4) mengungkapkan bahwa "media pembelajaran merupakan penghubung dalam proses belajar".
Penggunaan media pembelajaran akan memberikan dampak yang lebih banyak dan lebih berguna dibandingkan hanya dengan pembelajaran yang berpusat pada guru. Menurut Afandi (2015:80) "kelebihan media pembelajaran permainan ular tangga 
yaitu; (1) peserta didik belajar sambil bermain, (2) peserta didik tidak belajar sendiri, (3) memudahkan peserta didik belajar karena dibantu dengan gambar yang ada dalam ular tangga, dan (4) tidak memerlukan biaya mahal dalam membuat media pembelajaran permainan ular tangga".

Berdasarkan uraian latar belakang tersebut penelitian ingin menerapkan metode pembelajaran STAD melalui media ular tangga dengan tujuan meningkatkan kemampuan berpikir kritis peserta didik, selain itu hasil belajar IPS peserta didik kelas 2 SDN Kutowinangun 07 Kota Salatiga dapat meningkat.

\section{B. METODE PENELITIAN}

Penelitian yang dilakukan adalah jenis penelitian tindakan kelas (PTK). Menurut Arikunto (2014:3) PTK merupakan suatu pencermatan terhadap kegiatan belajar berupa sebuah tindakan yang sengaja dilakukan dan terjadi di dalam kelas secara bersama. Tujuan PTK adalah untuk mengadakan perbaikan dari kondisi pembelajaran. Penelitian ini dilakukan untuk meningkatkan kemampuan berpikir kritis dan hasil belajar IPS peserta didik kelas 2 SDN Kutowinangun 07
Salatiga pada semester genap tahun pelajaran 2017/2018 dengan materi peran dan kedudukan anggota keluarga. Peserta didik berjumlah 15 anak yang terdiri dari 6 peserta didik laki-laki dan 9 peserta didik perempuan. Penelitian ini dilakukan dalam 2 siklus dengan setiap siklusnya 3 pertemuan. Variabel bebas pada penelitian ini adalah model pembelajaran STAD dan media pembelajaran ular tangga. Sedangkan variable terikatnya adalah kemampuan berpikir kritis dan hasil belajar IPS peserta didik.

Pengumpulan data menggunakan teknik tes dan non tes. Teknik non tes berupa observasi, "observasi adalah suatu metode mengumpulkan data dengan cara mengamati setiap kejadian yang sedang berlangsung dan mencatatnya dengan alat observasi tentang hal-hal yang diamati dan diteliti" (Sanjaya, 2012:86). Lembar observasi ini digunakan untuk mengamati aktivitas peserta didik (kompetensi ranah afektif) sesuai indikator kemampuan berpikir kritis dan keterlaksanaan pembelajaran yang dilakukan dengan menggunakan model pembelajaran STAD berbantuan media ular tangga.

TABEL 3

KISI-KISI OBSERVASI KEMAMPUAN BERPIKIR KRITIS

\begin{tabular}{|c|l|l|}
\hline No & Aspek & Indikator yang diamati \\
\hline 1. & Pandai mendektesi masalah & Peserta didik mampu menyadari permasalahan yang disajikan. \\
\hline 2. & $\begin{array}{l}\text { Suka mengumpulkan data untuk pembuktian } \\
\text { faktual }\end{array}$ & $\begin{array}{l}\text { Peserta didik mampu menjelaskan/menuliskan data berdasar } \\
\text { permasalahan yang disajikan. }\end{array}$ \\
\hline $3 \cdot$ & Suka bertanya & $\begin{array}{l}\text { Peserta didik mampu bertanya dengan menggunakan } \\
\text { pertanyaan berpikir kritis }\end{array}$ \\
\hline $4 \cdot$ & Mampu menjelaskan gambar & $\begin{array}{l}\text { Peserta didik mampu menjelaskan maksud dari gambar yang } \\
\text { disajikan. }\end{array}$ \\
\hline $5 \cdot$ & Mampu menjelaskan pengertian, definisi & $\begin{array}{l}\text { Peserta didik mampu menjelaskan pengertian dan definisi teori } \\
\text { menurut bahasanya sendiri. }\end{array}$ \\
\hline 6. & $\begin{array}{l}\text { Mampu mendaftar segala akibat yang mungkin } \\
\text { terjadi atau alternatif pemecahan terhadap } \\
\text { masalah, ide, dan situasi }\end{array}$ & $\begin{array}{l}\text { Peserta didik mampu menjelaskan ide sebagai pemecahan } \\
\text { masalah. }\end{array}$ \\
\hline 7. & $\begin{array}{l}\text { Mampu menarik kesimpulan dari data yang telah } \\
\text { ada dan }\end{array}$ & $\begin{array}{l}\text { Peserta didik mampu menjelaskan kesimpulan berdasarkan } \\
\text { masalah yang disajikan. }\end{array}$ \\
\hline
\end{tabular}

(Lelana, 2010:41)

Untuk menghitung nilai observasi berpikir kritis menggunakan rumus:

$$
S=\frac{R}{N} \times 4
$$

Keterangan:

$$
\mathrm{S}=\text { Nilai } \quad \mathrm{R}=\Sigma \text { skor yang diperoleh }
$$

$\mathrm{N}=\Sigma$ skor maksimal, $4=$ Nilai maksimal (Mengadopsi dari Ngalim Purwanto, 2011:112)

TABEL 4

KRITERIA PENILAIAN SIKAP

\begin{tabular}{|c|c|}
\hline Rentang Nilai & Kriteria \\
\hline $3,51-4,00$ & SK (sangat kritis) \\
\hline $2,51-3,50$ & K (kritis) \\
\hline $1,51-2,50$ & CK (cukup kritis) \\
\hline $1,00-1,50$ & KK (kurang kritis) \\
\hline
\end{tabular}

Sumber: Permendikbud No. 104 tahun 2014
Teknik tes berupa soal uraian, tes ini digunakan untuk mengetahui hasil belajar pada kemampuan teori peserta didik (kompetensi ranah kognitif). Sudjana menekankan bahwa hasil belajar merupakan kemampuan yang diperoleh setelah proses belajar (Hardini: 2017:234).

Dalam penelitian ini butir soal yang dibuat berdasarkan indikator berpikir kritis. 
TABEL 5

ASPEK KEMAMPUAN BERPIKIR KRITIS

\begin{tabular}{|l|l|}
\hline \multicolumn{1}{|c|}{ Kategori } & \multicolumn{1}{c|}{ Indikator } \\
\hline \multirow{2}{*}{ Melakukan Klarifikasi dasar } & 1. Fokus pada pertanyaan \\
\cline { 2 - 2 } & 2. Menganalisis argumen \\
\hline Menilai dukungan dasar & 3. Menilai sumber yang dapat dipercaya \\
\hline \multirow{2}{*}{ Membuat Kesimpulan } & 4. Membuat Kesimpulan secara deduktif \\
\cline { 2 - 2 } Melakukan klarifikasi tingkat lanjut & 5. Membuat kesimpulan secara induktif \\
\cline { 2 - 2 } $\begin{array}{l}\text { Menerapkan strategi dan taktik dalam } \\
\text { menyelesaikan masalah }\end{array}$ & 8. Mendefinisikan asumsi \\
\hline
\end{tabular}

Adaptasi dari Nitko \& Brookhart (2011:234-236)

Penelitian ini dikatakan berhasil jika semua prosedur pembelajaran telah dilakukan dengan baik sesuai model pembelajaran STAD melalui media ular tangga. Sehingga dapat meningkatkan hasil belajar IPS $\geq 80 \%$ dari jumlah seluruh peserta didik dengan KKM $\geq 75$.

\section{HASIL DAN PEMBAHASAN}

Permainan ular tangga yang terdapat pada penelitian ini dipadukan dengan model pembelajaran STAD. Peserta didik dibentuk kelompok yang heterogen, dalam berkelompok peserta didik bermain ular tangga. Ular tangga pada penelitian ini dimodifikasi oleh penulis, di dalam ular tangga pada setiap nomor mempunyai gambar dan keterangan yang berbeda-beda sesuai dengan materi yang akan diajarkan. Di dalam ular tangga ini terjadap juga keterangan yang mengharuskan peserta didik untuk mengambil kartu soal lalu mengerjakannya bersama kelompok. Konsep penggunaan media pembelajaran permainan ular tangga dimodifikasi oleh penulis, penggunaan media pembelajaran ular tangga yang dikembangkan yaitu;

1. Pemain dibagi menjadi 4 kelompok, masingmasing kelompok terdiri dari 3-4 peserta didik yang heterogen.

2. Setiap kelompok diberikan masing-masing ular tangga, kartu soal/tugas yang ada pada ular tangga harus dikerjakan oleh kelompok.

3. Setiap anggota kelompok mempunyai bidak sendiri-sendiri, setiap anggota kelompok memulai permainan secara bergiliran dengan melempar dadu.

4. Saat bidak anggota kelompok berhenti pada angka tertentu dalam ular tangga yang terdapat tulisan "ambil dan kerjakan kartu soal", kelompok melihat soal/tugas yang ada lalu mengerjakannya.

5. Anggota kelompok yang sudah memahami materi dan mengetahui jawabannya menjelaskan kepada anggota kelompok lain.

6. Soal dan jawaban kelompok ditulis pada LKK (Lembar Kerja Kelompok) yang sudah disediakan. Begitu seterusnya sampai setiap kelompok mengerjakan soal yang terdapat pada ular tangga.

7. Jika kelompok sudah mengerjakan semua soal/tugas yang ada pada permainan ular tangga, permainan dikatakan sudah berakhir. Peserta didik boleh berhenti memainkan ular tangga, atau memainkannya sampai waktu yang diberikan oleh penulis habis.

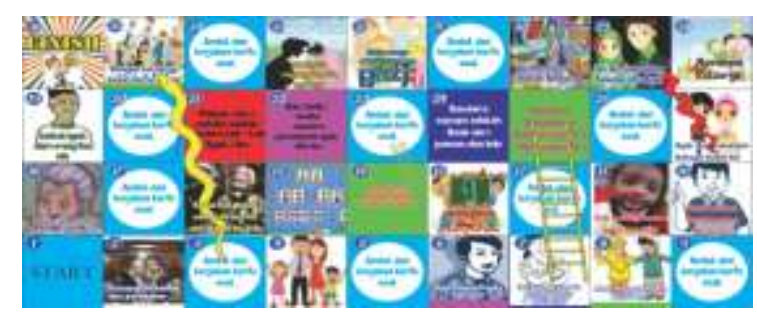

Gambar 1. Media pembelajaran ular tangga materi kedudukan keluarga

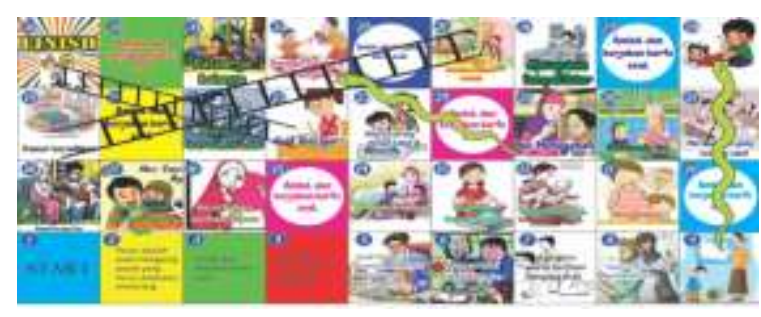

Gambar 2. Media Pembelajaran Ular Tangga Materi Peran Keluarga

\section{Pelaksanaan Penelitian}

a. Pra Tindakan

Berdasarkan Pra tindakan dilaksanakan pada tahap pra tindakan dilakukan untuk memperoleh data awal mengenai hasil belajar peserta didik pada mata pelajaran IPS materi peran dan kedudukan anggota keluarga sebelum dilakukan tindakan. Data yang diperoleh pada tahap pra tindakan ini didapat melalui observasi dan pre test.

TABEL 6

KETUNTASAN HASIL BELAJAR IPS PADA PRA TINDAKAN

\begin{tabular}{|c|c|l|c|c|}
\hline No & Skor & Ketuntasan & Jumlah & Persentase \\
\hline 1. & $<75$ & Tidak Tuntas & 11 & $73,3 \%$ \\
\hline 2. & $\geq 75$ & Tuntas & 4 & $26,7 \%$ \\
\hline
\end{tabular}




\begin{tabular}{|c|c|c|}
\hline Jumlah & 15 & 100\% \\
\hline Nilai tertinggi & \multicolumn{2}{|c|}{83} \\
\hline Nilai terendah & \multicolumn{2}{|c|}{27} \\
\hline Rata-rata kelas & \multicolumn{2}{|c|}{66,13} \\
\hline
\end{tabular}

Dari tabel 6 dapat dilihat bahwa hasil belajar peserta didik pada pelajaran IPS belum maksimal, hal ini ditunjukkan dari banyaknya peserta didik yang belum tuntas dalam belajarnya sesuai dengan Kriteria Ketuntasan Minimal (KKM) yang ditetapkan pada penelitian ini yaitu 75 . Terdapat 11 peserta didik $(73,3 \%)$ yang tidak tuntas, sedangkan 4 peserta didik (26,7\%) yang sudah tuntas dalam pembelajaran IPS. Hasil belajar peserta didik menunjukkan bahwa nilai rata-rata kelas adalah 66,13 dengan nilai tertinggi 83 dan terendah 27.

Kemampuan berpikir kritis peserta didik pada pra tindakan diambil dari observasi sebelum diadakan penelitian. Kemampuan berpikir kritis pada pra tindakan diamati oleh penulis dan teman sejawat. Berdasarkan pengamatan terdapat 5 indikator yang tergolong kriteria kurang kritis. peserta didik masih belum mampu dalam mendeteksi masalah, mngumupulkan data, memberikan alternatif solusi dan menarik kesimpulan. Peserta didik sudah mampu menyebutkan gambar tertapi penjelasannya kurang sesuai dan peserta didik dalam menjelaskan definisi/pengertian yang disampaikan kurang sesuai. Rata-rata kemampuan berpikir kritis peserta didik kelas 2 pada kriteria kurang kritis $(1,49)$, sedangkan penulis menginginkan pada penelitian ini kemampuan berpikir kritis peserta didik masuk dalam kriteria kritis $(\geq 2,51)$. Hal ini membuktikan bahwa kemampuan berpikir kritis dan hasil belajar peserta didik masih rendah.

\section{b. Siklus 1}

Siklus 1 terdiri dari 4 tahap yaitu perncanaan, pelaksanaan tindakan, observasi dan refleksi. Siklus 1 dilaksanakan sebanyak 3 kali pertemuan. Setiap pertemuan dilakukan observasi pada kegiatan yang dilakukan oleh penulis pada penerapan model STAD melalui media ular tangga dalam pembelajaran yang pengamatan dilakukan oleh teman sejawat. Observasi dilakukan juga terhadap aktivitas peserta didik untuk mengukur kemampuan berpikir kritis.

Pada setiap pertemuan diberikan kuis individu dan pada pertemuan ketiga peserta didik diberikan soal siklus 1. Berikut hasil pelaksanaan tindakan siklus I dengan menggunakan model pembelajaran STAD melalui media ular tangga.

TABEL 7

KEMAMPUAN BERPIKIR KRITIS SIKLUS I

\begin{tabular}{|c|c|c|c|c|c|c|c|}
\hline \multirow[t]{2}{*}{ No } & \multirow[t]{2}{*}{ Indikator Berpikir Kritis } & \multicolumn{3}{|c|}{ Nilai Berpikir Kritis } & \multicolumn{3}{|c|}{ Kriteria } \\
\hline & & $\mathbf{P 1}$ & P2 & $\mathbf{P 3}_{3}$ & $\mathbf{P 1}$ & P2 & P3 \\
\hline 1. & Pandai mendektesi masalah & 1.87 & 2.13 & 2.53 & CK & CK & $\mathrm{K}$ \\
\hline 2. & Suka mengumpulkan data untuk pembuktian faktual & 1.73 & 1.87 & 1.93 & CK & CK & CK \\
\hline 3. & Suka bertanya & 1.60 & 1.67 & 2.13 & CK & CK & CK \\
\hline 4. & Mampu menjelaskan gambar/kartu & 2.53 & 2.60 & 2.80 & $\mathrm{~K}$ & $\mathrm{~K}$ & $\mathrm{~K}$ \\
\hline 5. & Mampu menjelaskan pengertian, definisi & 1.93 & 2.53 & 2.60 & CK & $\mathrm{K}$ & $\mathrm{K}$ \\
\hline 6. & $\begin{array}{l}\text { Mampu mendaftar segala akibat yang mungkin terjadi } \\
\text { atau alternatif pemecahan terhadap masalah, ide, dan } \\
\text { situasi }\end{array}$ & 1.40 & 1.67 & 1.80 & KK & CK & $\mathrm{CK}$ \\
\hline 7 . & $\begin{array}{l}\text { Mampu menarik kesimpulan dari data yang telah ada } \\
\text { dan terseleksi }\end{array}$ & 1.47 & 1.60 & 1.73 & KK & CK & CK \\
\hline & Rata-rata kemampuan berpikir kritis & 1.79 & 2.01 & 2.22 & CK & CK & CK \\
\hline
\end{tabular}

Berdasarkan tabel 7 dapat dilihat bahwa kemampuan berpikir kritis peserta didik dari 7 indikator terdapat 3 indikator yang sudah masuk ke dalam kriteria kritis. Rata-rata kemampuan berpikir kritis peserta didik pada indikator menjelaskan gambar masuk dalam kriteria kritis yang artinya peserta didik sudah mampu menjelaskan gambar dengan tepat. Peserta didik sudah mampu menyampaikan definisi dengan tepat. Indikator ketiga yang masuk dalam kriteria kritis adalah peserta didik mampu menyadari masalah yang ada dan sesuai, walaupun hal ini terlihat pada pertemuan ketiga dengan 8 anak yang termasuk dalam kriteria kritis. peserta didik yang lain baru sampai pada tahap mampu menyadari masalah yang ada tapi kurang sesuai.

Selama proses belajar mengajar jumlah peserta didik yang aktif bertanya walaupun pertanyaannya belum berupa pertanyaan yang berpikir kritis ada 6 anak yang melakukannya dan hal ini dilakukan pada pertemuan ketiga, pada pertemuan pertama dan kedua peserta didik sudah ada yang bertanya walaupun pertanyaannya belum dirumuskan dengan baik hal ini masuk dalam kriteria cukup kritis. Dalam pengamatan selama 3 pertemuan peserta didik sudah mampu mengumpulkan data yang sesuai dengan masalah yang disajikan walaupun peserta didik belum menjelaskan permasalahannya, 
sedangkan peserta didik yang lain data yang dikumpulkan kurang sesuai, peserta didik masih belum teliti dalam menuliskan data berdasar permasalahan yang disajikan. Rata-rata kemampuan berpikir kritis peserta didik pada indikator suka mengumpulkan data untuk pembuktian faktual masuk dalam kriteria cukup kritis yaitu mampu mengumpulkan data tapi kurang sesuai.

Pada indikator mampu mendaftar segala akibat yang mungkin terjadi atau memberikan

\section{TABEL 8}

alternatif pemecahan terhadap masalah, ide, dan situasi masuk dalam kriteria cukup kritis yaitu peserta didik sudah bisa memberikan ide/jawaban walaupun kurang sesuai. Indikator terakhir yaitu mampu menarik kesimpulan dari data yang telah ada dan terseleksi masuk dalam kriteria cukup kritis yang artinya peserta didik dalam menyimpulkan pembelajaran dan masalah yang disajikan kurang sesuai, mereka belum teliti dan belum bisa mengutarakan kesimpulan menggunakan bahasa sendiri.

DATA FREKWENSI HASIL BELAJAR IPS SIKLUS I

\begin{tabular}{|c|c|c|c|c|c|c|c|}
\hline \multirow{2}{*}{ No } & \multirow{2}{*}{ Interval Nilai } & \multicolumn{3}{|c|}{ Frekwensi } & \multicolumn{3}{c|}{ Presentase } \\
\cline { 3 - 8 } & & P1 & P2 & P3 & P1 & P2 & P3 \\
\hline 1. & $87-100$ & 3 & 5 & 7 & $20 \%$ & $33,33 \%$ & $46,67 \%$ \\
\hline 2. & $73-86$ & 7 & 2 & 5 & $46,67 \%$ & $13,33 \%$ & $33,33 \%$ \\
\hline 3. & $59-72$ & 2 & 7 & 1 & $13,33 \%$ & $46,67 \%$ & $6,67 \%$ \\
\hline 4. & $45-58$ & 2 & - & 2 & $13,33 \%$ & - & $13,33 \%$ \\
\hline 5. & $31-44$ & 1 & 1 & - & $6,67 \%$ & $6,67 \%$ & - \\
\hline
\end{tabular}

Berdasarkan tabel 8 diketahui bahwa pada pertemuan pertama ada 3 peserta didik yang memperoleh nilai antara 87-100, 7 peserta didik yang memperoleh nilai antara 73-86, 2 peserta didik yang memperoleh nilai antara 59-72, 2 peserta didik yang memperoleh nilai antara $45^{-}$ 58, dan ada 1 peserta didik yang memperoleh nilai antara 31-44. Dengan nilai tertinggi yang diperoleh adalah 100 dan nilai terendah adalah 33. Rentang nilai yang cukup jauh membuat penulis harus membimbing peserta didik yang belum tuntas setelah pembelajaran berakhir. Pada pertemuan kedua ada 5 peserta didik yang memperoleh nilai antara 87-100, 2 peserta didik yang memperoleh nilai antara $73-86,7$ peserta didik yang memperoleh nilai antara 59-72, tidak ada peserta didik yang memperoleh nilai antara 45-58, dan ada 1 peserta didik yang memperoleh nilai antara 31-44. Nilai tertinggi adalah 95 dan terendah 43. Peserta didik yang memperoleh nilai paling rendah adalah peserta didik yang sama pada pertemuan pertama. Penulis setelah pembelajaran berakhir membimbing secara individu terhadap peserta didik tersebut.
Pada pertemuan ketiga yang menggunakan soal siklus I didapatkan hasil berupa 7 peserta didik memperoleh nilai 87-100, 5 peserta didik memperoleh nilai $73-86$, peserta didik yang memperoleh nilai 59-72 ada 1, peserta didik yang memperoleh nilai $45-58$ ada 2 anak, dan tidak ada peserta didik yang memperoleh nilai antara 31-44. Dengan nilai tertinggi 100 dan terendah 52, hasil belajar peserta didik mengalami peningkatan dilihat dari rentang nilai antara nilai tertinggi dan terendah sudah tidak terlalu jauh.

c. Siklus II

Pada siklus I ini rata-rata kemampuan berpikir kritis belum mencapai $\geq 2.51$ seperti yang diharapkan oleh penulis, sehingga penulis berupaya pada siklus II agar kemampuan berpikir kritis peserta didik dapat meningkat. Upaya yang dilakukan penulis adalah dengan lebih memancing peserta didik untuk mengungkapkan pendapat mereka, membuat pembelajaran semenarik mungkin, membimbing peserta didik dalam berdiskusi dan memberi motivasi kepada peserta didik.

TAHAP 9

KEMAMPUAN BERPIKIR KRITIS PADA SIKLUS II

\begin{tabular}{|c|c|c|c|c|c|c|c|}
\hline \multirow{2}{*}{ No } & \multirow{2}{*}{ Indikator Berpikir Kritis } & \multicolumn{3}{|c|}{ Nilai Berpikir Kritis } & \multicolumn{3}{|c|}{ Kriteria } \\
\hline & & P1 & P2 & P3 & P1 & P2 & P3 \\
\hline 1. & Pandai mendektesi masalah & 2.67 & 2.87 & 3.00 & $\mathrm{~K}$ & $\mathrm{~K}$ & $\mathrm{~K}$ \\
\hline 2. & Suka mengumpulkan data untuk pembuktian faktual & 2.33 & 2.60 & 2.67 & CK & $\mathrm{K}$ & $\mathrm{K}$ \\
\hline 3. & Suka bertanya & 2.53 & 2.80 & 3.00 & $\mathrm{~K}$ & $\mathrm{~K}$ & $\mathrm{~K}$ \\
\hline 4. & Mampu menjelaskan gambar/kartu & 2.93 & 3.00 & 3.13 & $\mathrm{~K}$ & $\mathrm{~K}$ & $\mathrm{~K}$ \\
\hline 5. & Mampu menjelaskan pengertian, definisi & 2.60 & 2.73 & 2.80 & $\mathrm{~K}$ & $\mathrm{~K}$ & $\mathrm{~K}$ \\
\hline 6. & $\begin{array}{l}\text { Mampu mendaftar segala akibat yang mungkin terjadi atau } \\
\text { alternatif pemecahan terhadap masalah, ide, dan situasi }\end{array}$ & 2.07 & 2.47 & 2.80 & $\mathrm{CK}$ & CK & $\mathrm{K}$ \\
\hline 7. & Mampu menarik kesimpulan dari data yang telah ada dan terseleksi & 1.87 & 2.20 & 2.53 & CK & CK & $\mathrm{K}$ \\
\hline & Rata-rata kemampuan berpikir kritis & 2.43 & 2.67 & 2.85 & CK & $\mathrm{K}$ & $\mathrm{K}$ \\
\hline
\end{tabular}


Berdasarkan tabel 9 dapat dilihat bahwa sudah ada kemajuan dibandingkan siklus I, ratarata kemampuan berpikir kritis masuk ke dalam kriteria kritis. Pada pertemuam ketiga siklus II ini kemampuan berpikir kritis peserta didik semua indikator sudah masuk ke dalam kriteria kritis. Pada indikator pandai mendeteksi masalah, peserta didik sudah menyadari masalah yang ada dan sesuai, tidak ada peserta didik yang tidak menyadari masalah yang ada. Indikator suka mengumpulkan data untuk pembuktian faktual mereka sudah mampu mengumpulkan data sesuai tetapi belum dapat menjelaskan permasalahannya, yang masuk dalam kriteria sangat kritis hanya ada 1 anak, dia mampu mengumpulkan data dan sesuai serta mampu menjelaskan permasalahan dengan bahasa mereka sendiri.

Pertanyaan yang diajukan peserta didik selama proses belajar mengajar sudah merupakan pertanyaan berpikir kritis, kegiatan ini dilakukan oleh 4 anak. Sedangkan 7 anak sudah mengajukan pertanyaan walaupun belum merupakan pertanyaan berpikir kritis. Hal ini sudah merupakan kemajuan yang pesat karena pada pra tindakan hanya ada 4 anak yang bertanya itupun mereka belum mampu merumuskan pertanyaan dengan benar. Indikator yang keempat yaitu menjelaskan gambar, rata-rata kemampuan berpikir kritis peserta didik tergolong dalam kriteria kritis yaitu penjelasan yang disampaikan sesuai dengan gambar. Indikator mampu menjelaskan pengertian/definisi pada pertemuan pertama ada

\section{TABEL 10}

DISTRIBUSI FREKWENSI HASIL BELAJAR IPS PESERTA DIDIK SIKLUS II

\begin{tabular}{|l|c|c|c|c|c|c|c|}
\hline \multirow{2}{*}{ No } & Interval & \multicolumn{3}{|c|}{ Frekwensi } & \multicolumn{3}{c|}{ Presentase } \\
\cline { 3 - 8 } & Nilai & P1 & P2 & P3 & P1 & P2 & P3 \\
\hline 1. & $90-100$ & 8 & 8 & 6 & $53,33 \%$ & $53,33 \%$ & $40 \%$ \\
\hline 2. & $81-89$ & - & 1 & 6 & - & $6,67 \%$ & $40 \%$ \\
\hline 3. & $72-80$ & 3 & 3 & 2 & $20 \%$ & $20 \%$ & $13,33 \%$ \\
\hline 4. & $63-71$ & 3 & 2 & 1 & $20 \%$ & $13,33 \%$ & $6,67 \%$ \\
\hline 5. & $54-62$ & 1 & 1 & - & $6,67 \%$ & $6,67 \%$ & - \\
\hline
\end{tabular}

Berdasarkan tabel 10 dapat dilihat bahwa pada pertemuan pertama terdapat 8 anak yang mendapat nilai antara 90-100, 3 anak yang mendapat nilai antara $72-80,3$ anak yang mendapat nilai $63-71$ dan 1 anak yang mendapat nilai antara 54-62. Dengan nilai tertinggi 100 dan terendah 55, rentang nilai antara nilai tertinggi dan terendah sudah mulai terpaut tidak cukup jauh ini membuktikan bahwa kemampuan peserta didik sudah mulai seimbang. Pada pertemuan kedua terdapat 8 anak yang mendapat nilai antara 90-100, 1 anak yang memperoleh nilai antara 81-89, 3 anak yang mendapat nilai antara 72-80, 2 anak
5 anak yang sudah mampu menyampaikan definisi yang sesuai, pada pertemuan kedua menjadi 7 anak dan meningkat menjadi 8 anak pada pertemuan ketiga, mereka masuk ke dalam kategori kritis. Sedangkan 2 anak masuk ke dalam kategori sangat kritis yang artinya definisi yang disampaikan peserta didik sudah sesuai dan menggunakan bahasa mereka sendiri.

Peserta didik yang sudah memberikan ide/masukan/jawaban sesuai dengan permasalahan yang disajikan pada saat diskusi kelompok maupun pada proses belajar mengajar terdapat 5 anak pada pertemuan pertama, pertemuan kedua ada 7 anak dan pada pertemuan ketiga ada 11 anak. Patut disayangkan pada indikator ini tidak ada peserta didik yang mampu menjelaskan sebab akibat dari masalah yang disajikan. Mereka harus dipancing terlebih dahulu oleh penulis baru mampu menjelaskan sebab akibatnya. Indikator terakhir yaitu mampu menarik kesimpulan dari data yang telah ada dan terseleksi, peserta didik sudah mampu menarik kesimpulan dengan sesuai. Terdapat 4 anak pada pertemuan pertama, pertemuan kedua ada 7 anak dan 8 anak pada pertemuan ketiga yang termasuk dalam kriteria kritis. Tidak ada peserta didik yang mampu menyimpulkan dengan bahasa mereka sendiri. Rata-rata kemampuan berpikir kritis peserta didik sudah mencapai $\geq 2.51$ artinya yang diharapkan penulis sudah terwujud, yaitu kemampuan berpikir kritis peserta didik masuk dalam kriteria kritis. 
bisa untuk memunculkan kemampuan berpikir kritis mereka. Peserta didik juga sudah memanfaatkan ular tangga sebagai sumber belajarnya karena peserta didik membaca keterangan dan mengamati gambar yang terdapat pada ular tangga bukan hanya lewat saja saat bidak mereka berjalan.

Pada pertemuan ketiga dapat dilihat terdapat 6 anak yang mendapat nilai antara 90100, 6 anak yang mendapat nilai 81-89, 2 anak

TABEL 11

REKAPITULASI KETUNTASAN HASIL BELAJAR PESERTA DIDIK PADA SIKLUS I

\begin{tabular}{|c|c|c|c|c|c|}
\hline No & Skor & Ketuntasan & $\begin{array}{c}\text { Kuis Individu } \\
\text { Pertemuan 1 }\end{array}$ & $\begin{array}{c}\text { Kuis Individu } \\
\text { Pertemuan 2 }\end{array}$ & $\begin{array}{c}\text { Soal Siklus } \\
\text { I }\end{array}$ \\
\hline $\mathbf{1}$ & $<75$ & Tidak tuntas & $66,67 \%$ & $53,33 \%$ & $\mathbf{2 6 , 6 7 \%}$ \\
\hline $\mathbf{2}$ & $\geq 75$ & Tuntas & $33,33 \%$ & $46,67 \%$ & $73,33 \%$ \\
\hline 3 & \multicolumn{2}{|c|}{ Rata-rata kelas } & 72,73 & 74,87 & 82,40 \\
\hline
\end{tabular}

\section{Analisis Data}

Berdasarkan tabel 11 ketuntasan hasil belajar peserta didik pada siklus I mengalami peningkatan. Rata-rata hasil belajar peserta didik mengalami kenaikan dari pertemuan pertama 72,73 menjadi 74,87 pada pertemuan kedua dan meningkat menjadi 82,40 pada pertemuan ketiga. Presentase peserta didik yang tuntas juga mengalami kenaikan dari $33,33 \%$ pada pertemuan pertama menjadi $46,67 \%$ pada pertemuan kedua dan mendapat nilai 63-71 dan tidak ada peserta didik yang mendapat nilai antara 54-62. Dengan nilai tertinggi 100 dan terendah 70 , walaupun jumlah peserta didik yang memperoleh nilai 90-100 menurun tetapi untuk rata-rata hasil belajar meningkat. yang mendapat nilai antara $72-80,1$ anak yang

TABEL 12

REKAPITULASI KETUNTASAN HASIL BELAJAR PESERTA DIDIK PADA SIKLUS II

\begin{tabular}{|c|c|c|c|c|c|}
\hline No & Skor & Ketuntasan & $\begin{array}{c}\text { Kuis Individu } \\
\text { Pertemuan 1 }\end{array}$ & $\begin{array}{c}\text { Kuis Individu } \\
\text { Pertemuan 2 }\end{array}$ & Soal Siklus II \\
\hline 1 & $<75$ & Tidak tuntas & $26,67 \%$ & $20 \%$ & $6,67 \%$ \\
\hline 2 & $\geq 75$ & Tuntas & $73,33 \%$ & $80 \%$ & $93,33 \%$ \\
\hline 3 & \multicolumn{2}{|c|}{ Rata-rata kelas } & 83,33 & 85 & 86,60 \\
\hline
\end{tabular}

Berdasarkan tabel 12 ketuntasan hasil belajar peserta didik pada siklus II, jumlah presentase peserta didik yang tuntas lebih banyak daripada jumlah presentase peserta didik yang tidak tuntas. Jumlah presentase peserta didik sudah melebihi keinginan dari penulis yaitu $\geq 80 \%$. Rata-rata kelas hasil belajar peserta didik juga meningkat.

\section{Pembahasan Hasil Penelitian}

Kemampuan berpikir kritis dan hasil belajar peserta didik siklus I ke siklus II materi peran dan kedudukan anggota keluarga meningkat cukup signifikan. Peningkatan kemampuan berpikir kritis dan nilai hasil belajar disebabkan perubahan model pembelajaran dalam proses belajar mengajar yang di dalamnya meliputi kegiatan dan interaksi untuk melatih dan mengembangkan kemampuan bepikir kritis peserta didik. Peningkatan kemampuan berpikir kritis dan hasil belajar disebabkan karena dalam penerapan model pembelajaran STAD melalui media ular meningkat menjadi 73,33\% pada pertemuan ketiga Tetapi presentase jumlah peserta didik yang mengalami ketuntasan belum memenuhi keinginan penulis yaitu 80\%, walaupun jumlah peserta didik yang tuntas sudah lebih banyak daripada jumlah peserta didik yang tidak tuntas. Sehingga perlu dilanjutkan pada kegiatan pembelajaran siklus II agar keinginan peneliti hasil belajar peserta didik tuntas sebanyak $\geq 80 \%$ dapat terwujud. tangga memiliki kelebihan-kelebihan. Kelebihan model pembelajaran STAD yaitu melibatkan peserta didik secara aktif dalam pembelajaran tidak hanya terfokus pada peneliti. Dalam pembelajaran ini peneliti dibantu dengan media pembelajaran ular tangga sehingga peserta didik dapat berpikir secara kongkrit. Peserta didik bekerja secara kelompok, adanya kelompok dalam pembelajaran ini berguna untuk memastikan bahwa semua anggota kelompok benar-benar belajar, dan lebih khususnya lagi adalah mempersiapkan anggota kelompoknya untuk dapat mengerjakan kuis individu dengan baik (Isjoni, 2013:35). Hal ini juga membuat peserta didik merasa senang, tidak tegang dan takut selama pelajaran berlangsung. Selain itu adanya penghargaan yang berupa hadiah yang diberikan pada kelompok yang mendapat nilai terbaik, dapat menumbuhkan persaingan antar kelompok dan membuat peserta didik menjadi semangat untuk belajar. Dengan suasana yang demikian itu 
mampu meningkatkan kemampuan berpikir kritis dan hasil belajar peserta didik.

Pemanfaatan media ular tangga secara efektif membantu peserta didik dalam mengembangkan pengetahuan, sikap, dan keterampilan dalam proses belajar mengajar. Peserta didik mempelajari materi dengan mencoba melalui pengalaman memecahkan masalah secara langsung dengan cara berdiskusi tidak sekedar mendengar dan membaca, sehingga peserta didik dapat memperoleh hasil belajar yang lebih baik serta meningkatkan kualitas berpikir peserta didik.

Model pembelajaran kooperatif tipe STAD merupakan pembelajaran yang menuntut peserta didik agar menggunakan dan melatih intelektual mereka, sehingga melatih peserta didik untuk meningkatkan kemampuan berpikirnya. Model STAD ini juga menuntut peserta didik untuk berperan aktif dalam menyusun pengetahuannya sendiri. Pada akhirnya proses penyusunan inilah yang akan meningkatkan kemampuan berpikir kritis mereka. Oleh karena itu, pembelajaran kooperatif tipe STAD ini sangat cocok digunakan untuk mengetahui kemampuan peserta didik dalam menguasai konsep (Nyeneng, 2013:9-10).

Hasil penelitian ini menunjukkan bahwa penerapan model pembelajaran STAD melalui media ular tangga dapat meningkatkan kemampuan berpikir kritis dan hasil belajar. Hasil kemampuan berpikir kritis siklus I ke siklus II materi peran dan kedudukan anggota keluarga meningkat cukup signifikan. Hal ini dapat dilihat dari hasil pengamatan selama proses belajar mengajar pada pembelajaran kondisi pra tindakan, siklus I dan siklus II. Pada pra tindakan ada 10 peserta didik $(66,67 \%)$ yang cukup kritis dan 5 peserta didik (33,33\%). Pada pra tindakan dan siklus I tidak ada peserta didik yang masuk dalam kriteria sangat kritis sedangkan pada siklus II terdapat 2 anak yang berpikir kritis. Pada pra tindakan dan siklus I terdapat peserta didik yang masuk dalam kriteria kurang kritis sedangkan pada siklus II tidak ada peserta didik yang masuk dalam kriteria kurang kritis. Pada siklus I pertemuan 1 terdapat 2 peserta didik (13,3\%) yang kritis, 8 peserta didik (53,4\%) yang cukup kritis, 5 peserta didik (33,3\%) yang kurang kritis. Pada siklus I pertemuan 2, 2 peserta didik (13,3\%) yang kritis, 8 peserta didik (53,4\%) yang cukup kritis, 5 peserta didik (33,3\%) yang kurang kritis. Pada siklus I pertemuan 3 terdapat 4 peserta didik (26,7\%) yang kritis, 9 peserta didik (6o\%) yang cukup kritis dan 2 peserta didik (13,3\%) yang kurang kritis. Pada siklus II pertemuan 1 terdapat 1 peserta didik $(6,7 \%)$ yang sangat kritis, 4 peserta didik (26,6\%) yang kritis, 10 peserta didik $(66,7 \%)$ yang cukup kritis, tidak ada peserta didik dalam kriteria kurang kritis. Pada siklus II pertemuan 2 terdapat 2 peserta didik (13,3\%) yang sangat kritis, 6 peserta didik (40\%) yang kritis, 7 peserta didik (46,7\%) yang cukup kritis. Pada pertemuan 3 siklus II terdapat 2 peserta didik (13,3\%) yang sangat kriris, 8 peserta didik $(53,4 \%)$ yang kritis, dan 5 peserta didik $(33,3)$ yang cukup kritis.

Rata-rata kemampuan berpikir kritis peserta didik pada pra tindakan 1,49 yang tergolong dalam kriteria kurang kritis, pada siklus I rata-rata kemampuan berpikir kritis peserta didik 2,22 yang masuk dalam kriteria cukup kritis pada siklus II meningkat menjadi 2,85 dengan kriteria kritis. Hasil kemampuan berpikir kritis ini melebihi dari yang ditentukan pada awal penelitian yaitu $\geq 2,51$. Sehingga dapat dikatakan bahwa penelitian ini berhasil untuk meningkatkan kemampuan berpikir kritis peserta didik.

Hasil belajar peserta didik juga mengalami peningkatan, pada pra tindakan rata-rata hasil belajar peserta didik adalah 66,13, setelah dilakukan pembelajaran dengan menggunakan model pembelajaran STAD melalui media ular tangga rata-rata hasil belajar peserta didik adalah 82,40 pada siklus I dan pada siklus II rata-ratanya meningkat menjadi 86,60. Pada awal penelitian, penulis menentukan keberhasilan penelitian jika didapatkan $\geq 80 \%$ peserta didik mendapat nilai memenuhi KKM yaitu $\geq 75$. Pada siklus I terdapat $73,33 \%$ peserta didik yang tuntas dan pada siklus II meningkat menjadi $93,33 \%$ peserta didik yang tuntas.

\section{SIMPULAN DAN SARAN}

Berdasarkan hasil penelitian yang telah dijabarkan dapat disimpulkan, penerapan Model Pembelajaran Student Teams Achievement Divisions (STAD) melalui Media Pembelajaran Ular Tangga dapat meningkatkan kemampuan berpikir kritis peserta didik pada pelajaran IPS materi Kedudukan dan Peran Anggota Keluarga di kelas 2 SD Negeri Kutowinangun 07. Hal ini dapat dilihat dari hasil pengamatan selama proses belajar mengajar rata-rata kemampuan berpikir kritis peserta didik pada pra tindakan 1,49 yang tergolong dalam kriteria kurang kritis, pada siklus I rata-rata kemampuan berpikir kritis peserta didik 2,22 yang masuk dalam kriteria cukup kritis pada siklus II meningkat menjadi 2,85 dengan kriteria kritis. Hasil kemampuan berpikir kritis ini melebihi dari yang ditentukan pada awal penelitian yaitu $\geq 2,51$.

Hasil belajar peserta didik juga mengalami peningkatan, hal ini dapat dilihat dari hasil belajar peserta didik pada pembelajaran kondisi pra tindakan, siklus I dan siklus II. Pada pra tindakan ada 4 peserta didik (26,67\%) yang tuntas, pada siklus I terdapat 11 
peserta didik $(73,33 \%)$ yang tuntas, pada siklus II ada 14 peserta didik $(93,33 \%)$ yang tuntas.

Adapun saran bagi sekolah adalah untuk mengembangkan lebih lanjut sehingga model pembelajaran STAD melalui media ular tangga menjadi lebih baik dan dapat dikembangkan untuk pembelajaran pada mata pelajaran yang lain, untuk peserta didik agar peserta didik harus lebih semangat dalam melakukan kerja sama dengan temannya dan meningkatkan keaktifan serta daya tarik terhadap pelajaran IPS yang menerapkan model pembelajaran STAD melalui media pembelajaran ular tangga sehingga hasil belajar meningkat. Bagi peneliti lain hendaknya penelitian ini dapat dijadikan acuan bagi penelitian selanjutnya sebagai upaya meningkatkan mutu dan kualias pendidikan.

\section{UCAPAN TERIMA KASIH}

Penulis mengucapkan terima kasih kepada Bapak Stefanus C. Relmasira, S.Pd., MSEd. selaku Pembimbing 1 dan Ibu Agustina Tyas Asri Hardini, S.Pd., M.Pd. selaku Pembimbing 2 yang senantiasa memberikan bimbingan, nasehat, dan motivasi kepada penulis sehingga penelitian ini selesai dengan baik.

\section{DAFTAR RUJUKAN}

[1] Arikunto, Suharsimi. 2009. Penelitian Tindakan Kelas. Bandung : Bumi Aksara.

[2] Daryanto. 2012. Media Pembelajaran. Bandung : PT Satu Nusa.

[3] Hosnan. 2014. Pendekatan Saintiifik dan Kontekstual dalam Pembelajaran Abad 21. Bogor : Ghalia Indonesia.

[4] Isjoni. 2013. Cooperative Learning: Mengembangkan Kemampuan Belajar Kelompok. Bandung: Alfabeta.

[5] Sanjaya, Wina . 2013. Strategi Pembelajaran Berorientasi Standar Proses Pendidikan. Jakarta : Kencana Prenada Media Group.

[6] Trianto. 2010. Model-Model Pembelajaran Inovatif Berorientasi Konstruktivistik. Jakarta : Prestasi Pustaka.

[7] Afandi, Rifki. 2015. Pengembangan Media Pembelajaran Permainan Ular Tangga Untuk Meningkatkan Motivasi Belajar Peserta didik dan Hasil Belajar IPS di Sekolah Dasar. JINoP (Jurnal Inovasi Pembelajaran) Vo: 1 No: 1 Hal: 77-89.

[8] Amir, Mohammad Faizal. Proses Berpikir Kritis Peserta didik Sekolah Dasar dalam Memecahkan Masalah Berbentuk Soal Cerita Matematika Berdasarkan Gaya belajar. Jurnal Math Educator Nusantara, 2015, 1.2.

[9] HARDINI, Agustina Tyas Asri; AKMAL, Arlita. PENERAPAN METODE SNOWBALL THROWING BERBANTUAN MEDIA KONKRET UNTUK MENINGKATKAN KEAKTIFAN DAN HASIL BELAJAR IPA PESERTA DIDIK KELAS IV SEKOLAH DASAR. JURNAL PENDIDIKAN DASAR PERKHASA, 2017, 3 .

[10] INDRIASIH, Aini. Pemanfaatan Alat Permainan Edukatif Ular Tangga Dalam Penerapan Pembelajaran
Tematik Di Kelas Iii Sd. Jurnal pendidikan, 2015, 16.2: 127-137

[11] Kristin, Firosalia. Keefektifan Model Pembelajaran Berbasis Budaya (PBB) untuk Meningkatkan Hasil Belajar IPS Peserta didik Kelas IV SD. 2013. PhD Thesis. UNY.

[12] KRISTIN, Firosalia. Efektivitas Model Pembelajaran Kooperatif Tipe Stad Ditinjau Dari Hasil Belajar Ips Peserta didik Kelas 4 SD. Scholaria: Jurnal Pendidikan dan Kebudayaan, 2016, 6.2: 74-79.

[13] NYENENG, Putu, et al. Pengaruh Kemampuan Berpikir Kritis Terhadap Penguasaan Konsep Melalui Pembelajaran Kooperatif Tipe Stad.Jurnal Pembelajaran Fisika Universitas Lampung, 1.3.

[14] Rahman, Abd. Penerapan Metode Snowball Throwing Untuk Meningkatkan Hasil Belajar IPS Peserta didik Kelas V Pada SDN No. 1 Pantolobete. Jurnal Kreatif Tadulako Online, 2013, 5.4

[15] RAKHMADHANI, Nuzul; YAMTINAH, Sri; UTOMO, Suryadi Budi. Pengaruh Penggunaan Metode Teams Games Tournaments Berbantuan Media Teka-Teki Silang Dan Ular Tangga Dengan Motivasi Belajar Terhadap Prestasi Peserta didik Pada Materi Koloid Kelas XI SMA Negeri 1 Simo Tahun Pelajaran 2011/2012. Jurnal Pendidikan Kimia, 2013, 2.4: 190197.

[16] Saipuddin, Surya. 2015. Pengembangan Tes untuk Mengukur Berpikir Kritis. http://wawasanedukasi.blogspot.co.id/2015/11/penge mbangan-tes-untuk-mengukur.html diunduh pada tanggal 1 November 2017.

[17] Sulistiana, Devita. 2015. Keefektifan Penerapan Paduan Model Pembelajaran Problem Solving dan Kooperatif Tipe STAD Untuk Meningkatkan Hasil Belajar dan Kemampuan Berpikir Kritis Peserta didik Kelas XII IPA. Cendekia Vol: 9 No: 2 Hal: 123-134.

\section{PROFIL PENULIS UTAMA}

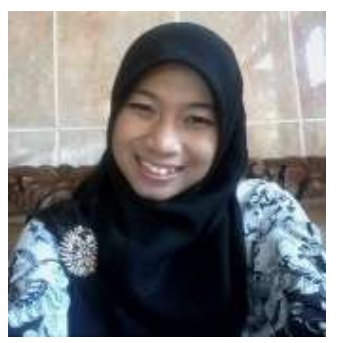

Penulis bernama lengkap "Dyah Anggraini”. Lahir di Salatiga Provinsi Jawa Tengah pada tanggal o8 Oktober 1987 dari pasangan Agus Suryanto dan Sri Priyatini. Penulis adalah anak kedua dari 4 bersaudara. Pendidikan sekolah dasar dimulai dari SDN Mangunsari 04 Salatiga pada tahun 1993 - 1999. Setelah itu melanjutkan pendidikan sekolah menengah ke SMPN 4 Salatiga pada tahun 1999 2002 melanjutkan pendidikan sekolah menengah atas di SMA MUHAMADIYAH Salatiga pada tahun 2002 - 2005. Kemudian penulis melanjutkan studi D2 ke perguruan tinggi di Program Guru Sekolah Dasar FKIP UKSW Salatiga pada tahun 2005-2007. Penulis melanjutkan S1 di Program Guru Sekolah Dasar FKIP UKSW Salatiga pada tahun 2016. Penulis bekerja sebagai ASN Kota Salatiga di SDN Kutowinngun 07 Salatiga. Kritik, saran, maupun hal-hal yang berkaitan dengan kelanjutan atau pengembangan dari hasil penelitian ini bisa dikirim ke email penulis di: dyahanggraini1987@gmail.com 